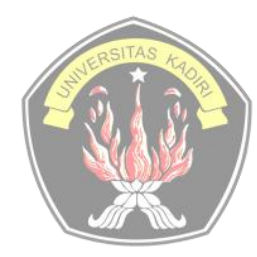

Tersedia online di

http://ojs.unik-kediri.ac.id/index.php/ekonika

do:

http://dx.doi.org/10.30737/ekonika.v5i2.1097

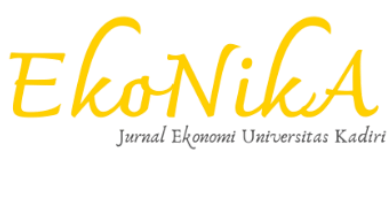

\title{
Pengaruh Kualitas Produk, Harga Dan Promosi Terhadap Minat Beli Konsumen Pada Pt. Satria Nusantara Jaya
}

Mohamad Rizal Nur Irawan ${ }^{1}$

1, Fakultas Ekonomi, Jurusan Manajemen, Universitas Islam Lamongan

email: ${ }^{1}$ rizalirawan@unisla.ac.id,${ }^{2}$ rijalunisla@gmail.com

\section{Artikel History:}

Artikel masuk : 17-08-2020

Artikel revisi : 17-09-2020

Artikel diterima : 29-09-2020

Keywords:

Kualitas Produk, Harga, Promosi

Dan Minat Beli Konsumen.

\begin{abstract}
ABSTRAK
Telah dilakukan penelitian tentang kualitas produ, harga dan promosi terhadapminat beli konsumen pada PT. Satria Nusantara Jaya. Penelitian ini bertujuan untuk mengetahui mengetahui kualitas produk, harga dan promosi terhadap minat beli konsumen pada PT. Satria Nusantara Jaya..Penelitian ini menggunakan Pendekatan Kuantitatif dengan menggunakan jenis penelitian Survey. Teknik pengambilan sampel yang digunakan adalah probability sampling.Populasi dalam penelitian ini adalah konsumen PT. Satria Nusantara Jaya, sehingga sampel yang terpilih sebanyak 100 konsumen yang dihitung dari rumus slovin. Analisis dilakukan dengan cara menyebarkan angket atau kuesioner, kemudian Alat analisis yang digunakan dalam penelitian ini adalah uji validitas, uji reliabilitas, asumsi klasik,uji regresi linier berganda, korelasi berganda, koefisien determinasi, uji t, uji F. dari analisis regresi linier berganda diperoleh persamaan $Y=-2,629+0,060 X_{1}+0,825 X_{2}+0,092 X_{3}+$ e. Hasil uji t Uji parsial telah dilakukan dan dihasilkan $\mathrm{t}_{\text {hitung }}$ lebih besar daripada $t_{\text {tabel }}\left(X_{1}=2,339>1,660 . X_{2}=26,450>1,660 . X_{3}=3,015<1,660\right.$. Sehingga dapat diketahui bahwa semua variabel bebas meliputi: kualitas produk, harga dan promosi mepunyai pengaruh persial terhadap minat beli konsumen pada PT. Satria Nusantara Jaya. Dan uji simultan telah dilakukan, dihasilkan $\mathrm{F}_{\text {hitung }}$ lebih besar daripada $F_{\text {abel }}(817,149>3,09)$. Sehingga dapat diketahui bahwa kualitas produk, harga dan promosi mempunyai pengaruh simultan terhadap minat beli konsumen PT. Satria Nusantara Jaya.
\end{abstract}

\section{ABSTRACT}

Research has been on product quality, price and promotion to the consumer buying interest in PT. Satria Nusantara Jaya. This research aims to know the product quality, price and promotion to the interest of buying consumers at PT. Satria Nusantara Jaya.. This research uses quantitative approaches using Survey research. Sampling techniques used are probability sampling. The population in this research is the consumer of PT. Satria Nusantara Jaya, so the samples were selected as much as 100 consumers calculated from the Slovin formula. Analysis is done by spreading a poll or questionnaire, then the analysis tool used in this research is the validity test, reliability tests, classical assumptions, multiple linear regression tests, multiple correlates, coefficient of 
determination, T-Test, F. Test of a multiple linear regression analysis obtained $\mathrm{Y}$ equation $=-2.629+0.060 \mathrm{X} 1+0.825 \mathrm{X} 2+$ $0.092 \mathrm{X} 3+\mathrm{E}$. T test result the partial test has been done and the resulting thitung is greater than the This $(\mathrm{X} 1=2,339>1,660 . \mathrm{X} 2$ $=26,450>1,660 . \mathrm{X} 3=3,015<1,660$. So it is possible to know that all of the free variables include: product quality, price and promotion, because of the impact of consumer buying interest in PT. Satria Nusantara Jaya. And the simultaneous test has been conducted, resulting fcount greater than fable $(817,149>3.09)$. So it can be known that product quality, price and promotion have a simultaneous influence on the interest of buying consumers of PT. Satria Nusantara Jaya.

\section{PENDAHULUAN}

Era globalisasi yang semakin dekat dimana perdagangan bebas menjadi suatu fenomena yang harus dihadapi dengan kesiapan yang matang dari berbagai faktor-faktor produksi yang dimiliki perusahaan. Pengaruh perdagangan bebas kini sudah sulit dibendung, semua Negaranegara di dunia akan merasakan dampaknya, untuk itu perusahaan harus disiapkan sebaik mungkin agar tidak tergilas perkembangan arus globalisasi dunia. Dalam mengembangkan usahanya para pelaku bisnis dituntut untuk lebih kreatif dan lebih berinovasi. Upaya mencari keuntungan merupakan fokus utama berwirausaha, karena tanpa keuntungan sebuah perusahaan tidak akan dapat bertahan. Ujung tombak perusahaan yaitu pemasaran harus dilakukan dengan baik dan tepat waktu mencapai target pasar yang telah ditetapkan dengan menghindari sekecil mungkin hal-hal yang infesiensi. Perilaku pembelian seseorang dapat dikatakan sesuatu yang unik, karena preferensi dan sikap terhadap obyek setiap orang berbeda. Selain itu konsumen berasal dari bebagai segmen, sehingga apa yang diinginkan dan dibutuhkan juga berbeda. Produsen juga harus memamahi perilaku konsumen terhadap produk yang ditawarkan dipasaran.

Dalam menjalankan bisnis, pelaku bisnis harus selalu mengamati dan mengikuti perubahan trend karena sangat berpengaruh terhadap minat beli konsumen. Seiring dengan perkembagan perekonomian, PT. Satria Nusantara Jaya terus menerus melakukan membangun perumahan-perumahan di daerah Lamongan untuk mencari konsumen. Kondisi seperti itulah yang pada akhirnya menyebabkan para pelaku usaha makin gencar berusaha untuk mencari solusi maupun program bisnis yang dapat meningkatkan daya saing perusahaan didalam bisnisnya. Namun demikian, meskipun perusahaan telah berusaha bersaing dan memberikan yang terbaik untuk konsumen belum tentu dapat menjamin akan berhasilnya usaha pencapaian 
tujuan perusahaan. Perusahaan menemukan masalah dalam promosi, dimana konsumen melihat harga yang mahal sehingga mempengaruhi minat beli konsumen. Perilaku pembelian seseorang dapat dikatakan sesuatu yang unik, karena preferensi dan sikap terhadap obyek setiap orang yang berbeda. Selain itu konsumen berasal dari berbagai segmen, sehingga apa yang diinginkan dan dibutuhkan juga berbeda. Masih banyak faktor yang berpengaruh terhadap minat beli masyarakat. Produsen perlu memahami perilaku konsumen terhadap produk yang ada di pasar. Selanjutnya perlu dilakukan berbagai cara untuk membuat konsumen tertarik terhadap produk yang dihasilkan.

Menurut (Kotler \& Keller, 2012) Promosi merupakan sebuah aktifitas komunikasi yang bertujuan untuk memperlancar arus produk, servis atau ide tertentu pada sebuah aliran distribusi. Hal ini merupakan sebuah usaha untuk membujuk calon konsumen untuk menerima, membeli, merekomendasikan atau menggunakan produk yang sedang dipromosikan. Secara singkat bisa dikatakan bahwa promosi suatu usaha untuk mempengaruhi sikap atau perilaku yang menerima untuk membujuk mereka agar menerima konsep yang ditawarkan. Upaya yang dilakukan dalam memasarkan suatu produk dengan melakukan promosi yang meliputi advertising, sales promotion, personal selling, public relation, direct marketing supaya calon konsumen lebih memahami produk yang ditawarkan. Sebelum melakukan promosi perusahaan harus membentuk ide yang tepat dan terpadu dan mencakup bauran promosi seperti iklan, penjualan tatap muka, penjualan mulut ke mulut atau dalam bentuk publisitas seperti seminar agar menghasilkan komunikasi yang baik misal harus bisa menceritakan kelebihan produk dan bisa membujuk para calon konsumen agar membeli produk yang kita tawarkan.

Selain Promosi Perusahaan harus memperhatikan produk yang akan dijual kepada konsumen sesuai dengan permintaan konsumen. Hal ini selaras dengan pendapat (Armstrong et al., 2014) dimana produk adalah segala sesuatu yang dapat ditawarkan ke pasar untuk mendapatkan perhatian, dibeli, digunakan atau dikonsumsi yang dapat memuaskan keinginan atau kebutuhan. Atau bisa kita tarik kesimpulan bahwa produk merupakan pemahaman dari produsen atas sesuatu yang bisa ditawarkan sebagai ide atau usaha dalam mencapai tujuan organisasi melalui pemenuhan kebutuhan kegiatan konsumen selaras dengan kapasitas daya beli pasar

Demikian pula penetapan harga yang sesuai dengan segmentasi dan sasaran pasar yang dituju. Perusahaan perlu melakukan aktifitas promosi yang tepat dan penetapan harga yang sesuai, sehingga mampu menarik minat beli konsumen. menurut (Kotler \& Keller, 2016) berpendapat "Harga adalah sejumlah uang yang dibebankan atas suatu produk atau jasa, atau Pengaruh Kualitas Produk, Harga Dan..... 
jumlah dari suatu yang ditukar konsumen atas manfaat-manfaat karena memiliki atau menggunakan produk atau jasa”. Semakin tidak konsistennya harga bisa mempengaruhi minat beli konsumen. Minat beli konsumen yang ditindaklanjuti akan menjadi keputusan pembelian yang akan berdampak terhadap penjualan dan pendapatan perusahaan.

Mengingat bahwa promosi, harga dan kualitasproduk merupakan salah satu faktor penting yang dapat meningkatkan minat beli, maka penulis tertarik untuk melakukan penelitian lebih dalam dengan judul "Pengaruh Kualitas Produk, Harga Dan Promosi Terhadap Minat Beli Pada PT. Satria Nusantara Jaya".

\section{TINJAUAN PUSTAKA}

Peneliti oleh (Nasution, 2014) dengan judul "Pengaruh Promosi Dan Harga Terhadap Minat Beli Perumahan Obama”yang merupakan study pada PT. Nailah Adi Kurnia Sei Mencirim Medan. Untuk mengetahui variabel bebas yang meliputi $\mathrm{X}_{1}$ (Promosi), $\mathrm{X}_{2}$ (Harga) serta variabel terikat Y (Minat beli). Maka alat analisis yang digunakan adalah Uji Validitas dan Reliabilitas, Uji Asumsi Klasik, Analisis Regresi Berganda, Analisis Koefisien Korelasi, Analisis Koefisien Determinasi (R2), Pengujian Hipotesis dengan Uji Parsial (uji t) dan Uji Simultan (uji F). Dari hasil penelitian menyatakan bahwa nilai Fhitung = 9,285 dengan nilai probabilitas yakni sebesar 0,000 <0,05. Dengan demikian H0 ditolak, untuk variabel keandalan menunjukkan nilai $\mathrm{t}=1,985$ dengan nilai signifikansi sebesar $=0,05 \leq 0.05$ dengan demikian berarti nilai signifikansi 0,000 adalah lebih kecil sama dengan dari 0,05 yang berarti menunujukkan bahwa promosi memiliki pengaruh signifikan terhadap minat beli . untuk variabel keandalan menunjukkan nilai $\mathrm{t}=2,506$ dengan nilai signifikansi sebesar $=0,014<0,05$ dengan demikian berarti nilai signifikansi 0,014 adalah lebih kecil dari 0,05 yang berarti menunujukkan bahwa daya harga memiliki pengaruh yang signifikan terhadap minat beli. untuk variabel keandalan menunjukkan nilai $\mathrm{t}=2,506$ dengan nilai signifikansi sebesar $=0,014<0,05$ dengan demikian berarti nilai signifikansi 0,014 adalah lebih kecil dari 0,05 yang berarti menunujukkan bahwa daya harga memiliki pengaruh yang signifikan terhadap minat beli. nilai R-Square (dilihat dari Adjusted R Square) sebesar 0,143, hal ini berarti 14,3\% variasi nilai Minat Beli ditentukan oleh variasi nilai promosi dan harga sedangkan sisanya 85,7\% minat beli dipengaruhi oleh variabel-variabel lainnya yang tidak diteliti dalam penelitian ini. kesimpulannya bahwa ada pengaruh signifikan promosi dan harga terhadap minat beli.

\section{Kualitas Produk}

Pengaruh Kualitas Produk, Harga Dan.... 
Kualitas Produk Menurut (Alma, 2016), kualitas produk adalah keseluruhan gabungan karakteristik barang dan jasa dari pemasaran, rekayasa, pembuatan dan pemeliharaan yang membuat produk dan jasa yang digunakan memenuhi harapan pelanggan. menurut (Mowen \& Minor, 2006) memberikan beberapa dimensi kualitas produk sebagai berikut :
a. Kinerja
b. Reliabilitas atau keandalan
c. Daya tahan
d. Keamanan

\section{Harga}

(Kotler \& Keller, 2016) mengemukakan bahwa harga merupakan satu satunya elemen bauran pemasaran yang menghasilkan pendapatan, elemenelemen lainnya menimbulkan biaya. Harga juga merupakan salah satu elemen bauran pemasaran yang paling fleksibel. Harga dapat diubah dengan cepat, tidak seperti ciri khas (feature) produk dan perjanjian distribusi. Indikator Harga Menurut (Stanton et al., 2007), indikator harga yaitu:

1. keterjangkauan harga produk

2. kesesuaian harga dengan kualitas produk

3. daya saing produk

4. kesesuaian dengan manfaat produk

\section{Promosi}

Menurut (Alma, 2016) adalah : "Promosi adalah sejenis komunikasi yang memberi penjelasan dan meyakinkan calon konsumen mengenai barang dan jasa dengan tujuan untuk memperoleh perhatian, mendidik, mengingatkan dan meyakinkan calon konsumen". Kesimpulannya promosi merupakan alat komunikasi dan penyampaian pesan yang dilakukan baik oleh perusahaan maupun perantara dengan tujuan memberikan informasi mengenai produk, harga dan tempat. Ada empat jenis kegiatan promosi menurut (Armstrong et al., 2014) antara lain :

1. Periklanan

2. Penjualan tatap muka

3. Publisitas

4. Promosi penjualan

5. Pemasaran langsung 


\section{Minat Beli Konsumen}

Menurut (Mowen \& Minor, 2006)berpendapat "Minat beli adalah sesuatu diperoleh dari proses belajar dan proses pemikiran yang yang membentuk suatu persepsi”. Minat beli ini menciptakan suatu motivasi yang terus terekam dalam benaknya dan menjadi suatu keinginan yang sangat kuat yang pada akhirnya ketika seorang konsumen harus memenuhi kebutuhannya akan mengaktualisasikan apa yang ada di dalam benaknya itu. Indikator Minat Beli Adapun Indikator-indikator minat beli menurut (Wibowo, 2016) sebagai berikut:

1) Ketertarikan

2) Perhatian

3) Pencarian informasi

\section{Hipotesis}

1. Diduga variabel kualitas Produk, Harga, dan Promosi mempunyai pengaruh secara parsial terhadap Minat Beli Konsumen pada PT.Satria Nusantara Jaya

2. Diduga variabel Kualitas Produk, Harga dan Promosi, mempunyai pengaruh secara simultan terhadap Minat Beli Konsumen pada PT.Satria Nusantara Jaya

3. Diduga variabel Harga berpengaruh paling dominan terhadap Minat Beli Konsumen pada PT.Satria Nusantara Jaya.

\section{METODE PENELITIAN}

\section{Waktu dan Lokasi Penelitian}

Penelitian ini akan dilakukan pada 20 November sampai 20 April 2020 pada PT. Satria Nusantara Jaya di Jl. Basuki rahmat no.113 Lamongan (Lokasi perumahan desa. Tanjung kec. Lamongan perum Griya Asri Nusantara).

\section{Jenis Penelitian}

Sesuai dengan tujuan penelitian, yaitu melihat pengaruh kualitas produk, harga, promosi terhadap minat beli konsumen, maka penelitian ini dapat digolongkan pada penelitian deskriptif kuantitatif yaitu prosedur pemecahan masalah yang diselidiki dengan menggambarkan atau melukiskan keadaan subjek atau objek penelitian berdasarkan fakta fakta yang tampak atau sebagaimana adanya

\section{Teknik Penarikan Sampel}

\section{Populasi}


Menurut (Sugiyono, 2016), populasi adalah adalah wilayah generalisasi yang terdiri atas pbyek atau subyek yang mempunyai kualitas dan karakteristik tertentu yang diterapkan oleh peneliti untuk dipelajari dan ditarik kesimpulannya. Dari pernyataan tersebut dapat disimpulkan bahwa populasi bukan hanya orang saja, tetapi juga obyek atau benda-benda alam lain Populasi dalam penelitian ini adalah konsumen dari PT. Satria Nusantara Jaya yang berjumlah 600 konsumen.

\section{Sampel}

Berdasarkan dari hasil perhitungan menggunakan rumus slovin maka yang akan menjadi sampel dari penelitian ini sejumlah 100 konsumen hal ini dilakukan untuk mempermudah dalam pengelolaan data dan untuk hasil pengujian yang lebih baik. dalam pengambilan anggota sampel menggunakan teknik Metode dalam penelitian ini nonprobability sampling dengan teknik purposive.

\section{Metode Pengumpulan Data}

Jika dilihat dari sumber datanya maka pengumpulan data dapat menggunkan sumber data primer dan data sekunder. Adapun metode yang digunakan penulis dalam proses pengumpulan data adalah :

\section{Sumber Data}

Terdapat 2 jenis sumber data yang digunakan dalam penelitian ini, yaitu :

1. Data primer

Data primer, didapatkan secara langsung dari jawaban responden melalui observasi, wawancara dan kuisioner. Alat yang digunakan dalam pembuatan kuisioner adalah skala likert, untuk menangkap kesan, tanggapan, sikap, persepsi responden. Responden menjawab dengan mengungkapkan taraf atau intensitas setuju sampai tidak setuju terhadap pertanyaan, skor tersebut dapat dijumlahkan atau rata-rata

2. Data sekunder

Pengumpulan data sekunder dalam penelitian ini dilakukan melalui studi kepustakaan dengan tujuan untuk memperoleh literatur pada penelitian terdahulu dan teori penunjang, juga didapat dari Fakultas ekonomi Universitas Islam Lamongan.

\section{Teknik Pengambilan Data}

Teknik pengambilan data pada penelitian ini dilakukan dengan cara penyebaran kuesioner kepada konsumen PT. Satria Nusantara. 


\section{Operasional Variabel}

Variabel yang digunakan dalam penelitian ini dibagi menjadi 3 variabel $\mathrm{X}$, yaitu kualitas produk $\left(\mathrm{X}_{1}\right)$ dengan indikator Reliabilitas atau keandalan, Daya tahan, Keamanan.

$\operatorname{Harga}\left(\mathrm{X}_{2}\right)$ dengan indikator . keterjangkauan harga produk, kesesuaian harga dengan kualitas produk, daya saing produk, kesesuaian dengan manfaat produk.

Promosi $\left(\mathrm{X}_{3}\right)$ dengan indikator Periklanan Penjualan tatap muka, Publisitas, Promosi penjualan, Pemasaran langsung

Sedangkan untuk variabel Y adalah Minat beli konsumen dengan indikator Ketertarikan, Perhatian, Pencarian informasi.

\section{Metode Analisis Data}

1. Analisa deskriptif

Menurut (Ghozali, 2016) penelitian deskriptif adalah suatu penelitian yang bertujuan membuat diskriptif, gambaran, atau lukisan secara sistematis, faktual dan akurat mengenai fakta-fakta, sifat-sifatdan hubungan antar fenomena yang sedang diteliti.

\section{Uji Hipotesis}

Uji hipotesis dalam penelitian ini menggunakan uji t parsial dan uji F simultan, yaitu dilakukan dengan cara pengujian melalui aplikasi spss statistics 2.0 kepada seluruh data yang didapat dari hasil kuisioner yang diberikan kepada responden menggunakan uji t dan uji $\mathrm{F}$, untuk mengetahui pengaruh variabel independent terhadap variabel dependent secara parsial dan simultan.

kriteria untuk pengujian hipotesis secara parsial sebagai berikut :

a. Jika $t_{\text {hitung }}<\mathrm{t}_{\text {tabel }}$ maka maka $\mathrm{H}_{0}$ diterima, artinya variabel independent secara parsial tidak berpengaruh terhadap variabel dependent.

Jika $t_{\text {hitung }}>t_{\text {tabel }}$ maka $\mathrm{H}_{0}$ ditolak, artinya variabel independent secara parsial berpengaruh terhadap variabel dependent.

Kemudian output hasil pengujian data dilakukan pengukuran pada kurva uji t untuk melihat pengaruh variabel independent terhadap variabel dependent secara parsial.

Berikut kurva uji t:

\section{Daerah Penolakan $\mathrm{H}_{0} \quad$ Daerah Penolakan $\mathrm{H}_{0}$}

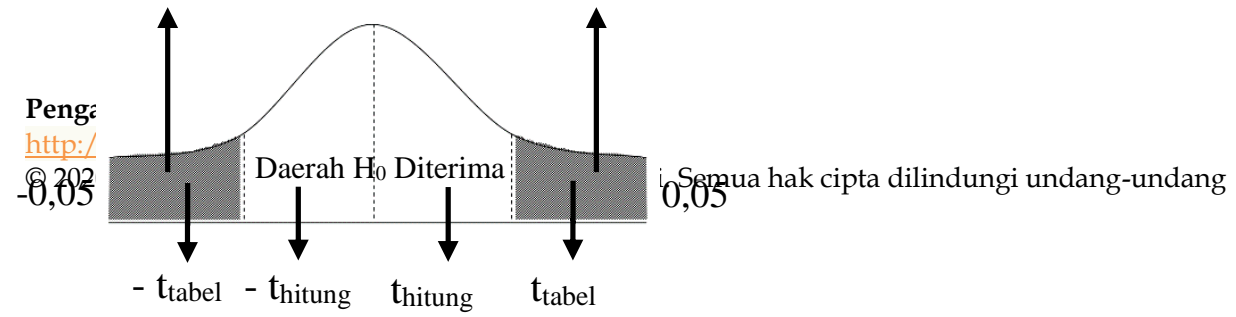


kriteria untuk pengujian hipotesis secara simultan sebagai berikut :

a. Jika $\mathrm{F}_{\text {hitung }}<\mathrm{F}_{\text {tabel }}$ maka maka $\mathrm{H}_{0}$ diterima, artinya variabel independent secara simultan tidak berpengaruh terhadap variabel dependent.

b. Jika $\mathrm{t}$ hitung $>\mathrm{t}$ tabel maka $\mathrm{H}_{0}$ ditolak, artinya variabel independent secara simultan berpengaruh terhadap variabel dependent.

Kemudian output hasil pengujian data dilakukan pengukuran pada kurva uji t untuk melihat pengaruh variabel independent terhadap variabel dependent secara simultan.

Berikut kurva uji F:

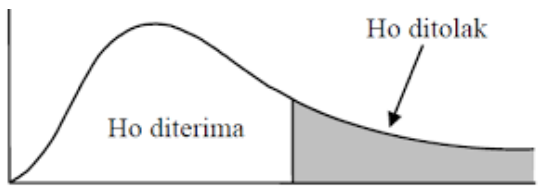

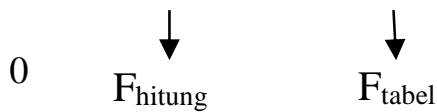

Kesimpulan pengujian dilakukan dengan membandingkan hasil pengujian dengan daerah penerimaan sebagai berikut :

a. Untuk mengetahui pengaruh variabel independent terhadap variabel dependent secara parsial dengan melakukan pengujian menggunakan uji t.

b. Untuk mengetahui pengaruh variabel independent terhadap variabel dependent secara simultan dengan melakukan pengujian menggunakan uji F.

Untuk mengetahui variabel independent manakah yang memiliki pengaruh paling dominan dilakukan dengan cara melihat membandingkan hasil thitung manakah yang menunjukkan hasil paling besar pada perhitungan uji t.

\section{Interpretasi Hasil Pengujian Hipotesis}

\section{Hasil uji t pengaruh variabel secara parsial}

Tabel 1 


\section{Coefficients $^{\mathrm{a}}$}

\begin{tabular}{|c|c|c|c|c|c|c|c|}
\hline \multirow[t]{2}{*}{ Model } & \multicolumn{2}{|c|}{$\begin{array}{l}\text { Unstandardized } \\
\text { Coefficients }\end{array}$} & \multirow{2}{*}{\begin{tabular}{|l}
$\begin{array}{l}\text { Standardize } \\
\text { d } \\
\text { Coefficients }\end{array}$ \\
Beta
\end{tabular}} & \multirow[t]{2}{*}{$\mathrm{T}$} & \multirow[t]{2}{*}{ Sig. } & \multicolumn{2}{|c|}{$\begin{array}{l}\text { Collinearity } \\
\text { Statistics }\end{array}$} \\
\hline & $\mathrm{B}$ & $\begin{array}{l}\text { Std. } \\
\text { Error }\end{array}$ & & & & Tolerance & VIF \\
\hline \multirow{4}{*}{ TOTALX2 } & -2.629 & .388 & & -6.783 & .000 & & \\
\hline & .060 & .026 & .059 & 2.339 & .021 & .610 & 1.639 \\
\hline & .825 & .031 & .877 & $\begin{array}{l}26.45 \\
0\end{array}$ & .000 & .357 & 2.801 \\
\hline & .092 & .030 & .088 & 3.015 & .003 & .465 & 2.149 \\
\hline
\end{tabular}

a. Dependent Variable: Minat Beli konsumen

Sumber :Output statistik SPSS 20 yang diolah 2020

1. Pengaruh Kualitas Produk Terhadap Minat Beli Konsumen Pada PT. Satria Nusantara Jaya

1. Dari hasil uji $t$ untuk variabel kualitas produk menunjukkan bahwa $t_{h i t u n g} 2.339>t_{\text {tabel }}$ 1,660 dengan nilai signifikan $0,021<0,05$ maka $\mathrm{H}_{0}$ ditolak yang berarti ada pengaruh yang signifikan antara $\mathrm{X}_{1}$ dengan variabel $\mathrm{Y}$, yang artinya bahwa ada pengaruh yang signifikan antara kualitas produk terhadap terbentuknya minat beli konsumen.

Hipotesis yang dibangun sebelumnya ditolak. Hal ini didukung oleh penelitian terdahulu yang dilakukan yang dilakukan oleh (Nainggolan \& Heryenzus, 2018) yang mana variabel nya berpengaruh secara parsial terhadap minat beli konsumen.

\section{Pengaruh Harga Terhadap Minat Beli Konsumen Pada PT. Satria Nusantara Jaya}

Harga $\left(\mathrm{X}_{2}\right)$ berdasarkan hasil uji statistik t, didapatkan hasil uji statistik t, didapatkan hasil thitung untuk variabel harga $\left(\mathrm{X}_{2}\right)$ sebesar 26,450 dengan taraf nilai signifikan $\alpha=0,05$ maka $t_{\alpha / 2}$; $d f=n-k-1=100-3-1=96$ maka diperoleh $t_{\text {tabel }}=1,660$, maka $t_{\text {hitung }}>t_{\text {tabel }}$ $(26,450>1,660)$ maka $\mathrm{H}_{0}$ ditolak yang berarti ada pengaruh yang signifikan antara $\mathrm{X}_{2}$ dengan variabel $\mathrm{Y}$, yang artinya bahwa ada pengaruh yang signifikan antara harga terhadap terbentuknya minat beli konsumen.

. Hipotesis yang dibangun sebelumnya ditolak. Hal ini didukung oleh penelitian terdahulu yang dilakukan Oleh (Daud et al., 2018; Pangastuti et al., 2019) dalam penelitiannya harga berpengaruh signifikan terhadap minat beli konsumen.

3. Pengaruh Promosi Terhadap Minat Beli Konsumen Pada PT. Satria Nusantara Jaya 
Promosi $\left(\mathrm{X}_{3}\right)$ berdasarkan hasil uji statistik $\mathrm{t}$, didapatkan hasil uji statistik t, didapatkan hasil thitung untuk variabel promosi $\left(\mathrm{X}_{3}\right)$ sebesar 3,015 dengan taraf nilai signifikan $\alpha=0,05$ maka $\mathrm{t}_{\alpha / 2} ; \mathrm{df}=\mathrm{n}-\mathrm{k}-1=100-3-1=96$ maka diperoleh $\mathrm{t}_{\text {tabel }}=1,660$, maka $t_{\text {hitung }}>t_{\text {tabel }}(3,015>1,660)$ maka $H_{0}$ ditolak yang berarti ada pengaruh yang signifikan antara $\mathrm{X}_{3}$ dengan variabel $\mathrm{Y}$, yang artinya bahwa ada pengaruh yang signifikan antara promosi terhadap terbentuknya minat beli konsumen.

Hipotesis yang dibangun sebelumnya ditolak. Hal ini didukung Oleh (Ernawati, 2019; Nasution, 2014) dalam penelitiannya promosi berpengaruh secara signifikan terhadap minat beli konsumen.

\section{Hasil Uji F Pengaruh Variabel Secara Simultan}

Tabel 2

Hasil uji F

ANOVA $^{a}$

\begin{tabular}{|ll|l|l|l|l|l|}
\hline \multicolumn{1}{|l|}{ Model } & $\begin{array}{l}\text { Sum of } \\
\text { Squares }\end{array}$ & Df & $\begin{array}{l}\text { Mean } \\
\text { Square }\end{array}$ & F & Sig. \\
\hline \multirow{4}{*}{1} & Regression & 550.983 & 3 & 183.661 & 817.149 & $.000^{\mathrm{b}}$ \\
& Residual & 21.577 & 96 & .225 & & \\
& Total & 572.560 & 99 & & & \\
\hline
\end{tabular}

a. Dependent Variable: Minat Beli Konsumen

b. Predictors: (Constant), TOTALX3, TOTALX1, TOTALX2

Sumber data SPSS 2020

Dari tabel diatas diperoleh $F_{\text {hitung }}=817,149$ sedangkan $F_{\text {tabel }}$ sebesar 3,09 Dimana $F_{\text {tabel }}$ diambil menggunakan rumus $\mathrm{df}=(\mathrm{n}-\mathrm{k}-1)$ yaitu $\mathrm{df}=100-3-1=96$, sehingga menghasilkan $\mathrm{F}_{\text {tabel }}$ 3,09 sehingga dapat disimpulkan bahwa $\mathrm{F}_{\text {hitung }}>\mathrm{F}_{\text {tabel }}$ maka $\mathrm{H}_{0}$ ditolak yang artinya bahwa variabel bebas (kualitas produk, harga dan promosi ) secara bersama-sama mempunyai pengaruh yang signifikan terhadap membentuk minat beli konsumen.

\section{Variabel Dominan}

Dari hasil uji t menunjukkan bahwa variabel harga adalah variabel yang paling dominan mempengaruhi minat beli konsumen pada PT. Satria Nusantara Jaya dengan pembuktian bahwa $\left(\mathrm{X}_{2}\right)$ memiliki nilai $t_{\text {hitung }} 26,450$ lebih besar dari variabel kualitas produk $\left(\mathrm{X}_{1}\right)$, promosi $\left(\mathrm{X}_{3}\right)$

\section{SIMPULAN \& SARAN}

\section{Simpulan}

1. Pengujian secara parsial Pengaruh Kualitas Produk, Harga Dan Promosi Terhadap Minat Beli Konsumen 
a. Berdasarkan pengujian hipotesis secara parsial diperoleh nilai thitung variabel kualitas produk lebih besar dari tabel dan nilai signifikan yang diperoleh lebih kecil dari 0,05, sehingga $\mathrm{H} 0$ ditolak dan $\mathrm{H} 1$ diterima, artinya kualitas produk berpengaruh secara parsial dan signifikan terhadap minat beli konsumen.

b. Berdasarkan pengujian hipotesis secara parsial diperoleh nilai thitung variabel harga lebih besar dari $t_{\text {tabel }}$ dan nilai signifikan yang diperoleh lebih kecil dari 0,05, sehingga $\mathrm{H} 0$ ditolak dan $\mathrm{H} 1$ diterima, artinya harga berpengaruh secara parsial dan signifikan terhadap minat beli konsumen.

c. Berdasarkan pengujian hipotesis secara parsial diperoleh nilai thitung variabel promosi lebih besar dari tabel dan nilai signifikan yang diperoleh lebih kecil dari 0,05 sehingga $\mathrm{H} 0$ ditolak dan $\mathrm{H} 1$ diterima, artinya promosi berpengaruh secara parsial dan signifikan terhadap minat beli konsumen.

Hasil penelitian ini sejalan dengan hasil penelitian sebelumnya yang dilakukan oleh (Nainggolan \& Heryenzus, 2018) dengan judul Analisis Faktor-Faktor Yang Mempengaruhi Minat Beli Konsumen Dalam Membeli Rumah Di Kota Batam. Dengan hasil seluruh variabel bebasnya mempunyai pengaruh secara parsial dan signifikan terhadap variabel terikatnya. Oleh (Septiani, 2018) (Pengaruh Promosi Dan Produk Terhadap Minat Beli) yang seluruh variabel bebasnya berpengaruh secara signifikan terhadap variabel terikatnya. Oleh (Nasution, 2014) (Pengaruh Promosi Dan Harga Terhadap Minat Beli Perumahan Obama) seluruh variabel bebasnya berpengaruh secara parsial. Oleh (Daud et al., 2018) (pengaruh kualitas produk, citra merek, dan harga terhadap keputusan pembelian sepeda motor merek Honda) dengan hasil suluruh variabel bebasnya berpengaruh secara parsial dan signifikan terhadap variabel terikatnya. Oleh (Ernawati, 2019) Analisis Pengaruh Kualitas Produk, Inovasi Produk, Dan Promosi Terhadap Keputusan Pembelian Produk "Hi Jack Sandals" dengan hasil seluruh variabel bebasnya berpengaruh secara parsial.dan pengujian uji $\mathrm{F}$ variabel bebasnya berpengaruh secara bersamasama terhadap variabel terikat.

2. Pengujian secara simultan pengaruh kualitas produk, harga dan promosi terhadap minat beli konsumen. 
Berdasarkan pengujian secara simultan dihasilkan nilai $F_{\text {hitung }}$ lebih besar dari pada $\mathrm{F}_{\text {tabel, }}$ dengan demikian dapat disimpulkan bahwa variabel kualitas produk, harga dan promosi secara bersama-sama memiliki pengaruh yang positif terhadap minat beli konsumen.

Hasil penelitian ini sejalan dengan hasil penelitian sebelumnya yang dilakukan oleh (Tegowati, 2019) dengan judul Pengaruh Desain Produk, Kualitas Produk, Promosi Dan Layanan Purna Jual Terhadap Keputusan Pembelian Konsumen. Dengan hasil seluruh variabel bebasnya mempunyai pengaruh secara bersama-sama terhadap variabel terikatnya. Oleh (Pangastuti et al., 2019) dengan judul Pengaruh Kualitas Produk Dan Harga Terhadap Keputusan Pembelian Produk Kosmetik Wardah. Dengan hasil seluruh variabel bebasnya mempunyai pengaruh secara bersama-sama terhadap variabel terikatnya. Oleh (Fernando \& Aksari, 2017) dengan judul Pengaruh Kualitas Produk, Harga, Promosi Dan Distribusi Terhadap Keputusan Pembelian. Yang hasilnya seluruh variabel bebasnya mempunyai pengaruh secara bersama-sama terhadap variabel terikatnya. Oleh (Nasution, 2014) (Pengaruh Promosi Dan Harga Terhadap Minat Beli Perumahan Obama) seluruh variabel bebasnya berpengaruh secara bersamasama terhadap variabel terikatnya. (Daud et al., 2018) (pengaruh kualitas produk, citra merek, dan harga terhadap keputusan pembelian sepeda motor merek Honda) dengan hasil seluruh variabel bebasnya berpengaruh secara bersama-sama terhadap variabel terikatnya.

3. Pengujian regresi linier berganda pengaruh kulaitas produk, harga dan promosi terhadap minat beli konsumen.

Berdasarkan dari hasil uji regresi linier berganda menyatakan bahwa harga berpengaruh paling doniman terhadap minat beli konsumen .Karena nilai Standardized Coefficients (Beta) variabel harga terlihat paling tinggi diantara variabel lainnya.

Hasil penelitian ini bertolak belakang dengan hasil penelitian sebelumnya yang dilakukan oleh (Fernando \& Aksari, 2017) dengan judul Pengaruh Kualitas Produk, Harga, Promosi Dan Distribusi Terhadap Keputusan Pembelian. Dengan hasil yang memiliki nilai Standardized Coeffisients (Beta) paling tinggi adalah variabel kualitas produk. Oleh (Daud et al., 2018) (pengaruh kualitas produk, citra merek, dan harga terhadap keputusan pembelian sepeda motor merek Honda) Dengan hasil yang memiliki nilai Standardized Coeffisients (Beta) paling tinggi adalah variabel kualitas produk. 
Sejalan dengan penelitian sebelumnya yang dilakukan oleh (Nasution, 2014) (Pengaruh Promosi Dan Harga Terhadap Minat Beli Perumahan Obama) Dengan hasil yang memiliki nilai Standardized Coeffisients (Beta) paling tinggi adalah variabel.

\section{DAFTAR PUSTAKA}

Andalusi,Ratih (2018). Pengaruh Kualitas Pelayanan, Harga, Dan Kualitas Produk Terhadap Kepuasan Pelanggan Instrumen Penunjang Laboratorium. J. Madani. Vol. 1, 307.

Annisa Putri Sabrina, Nur. Elpawati.dan Achmad Tjachja Nugrah. (2018). Analisis Pengaruh Citra Merek, Kualitas Produk, Harga Dan Diferensiasi Produk Terhadap Keputusan Pembelian Pizza Hut Di Jakarta Barat . Jurnal Agribisnis, Vol. 12.150.

Aswan, Hidayat. 2013. Analisis Pengaruh Kualitas Produk, Promosi dan Persepsi Harga Terhadap Minat Bell Ulang Pelanggan Voucher Isi Ulang XL di Universitas Semarang. Jurnal Fakultas Ekonomi Universitas Semarang. 2 (5): 59-78.

Daud, I., Defriansyah, D., \& Welyy. (2016). Pengaruh Citra Merek, Harga Dan Kualitas Produk Terhadap Keputusan Pembelian Smartphone Samsung (Studi Kasus Mahasiswa Universitas Sriwijaya Indralaya. Jurnah Ilmiah Manajemen Bisnis Dan Terapan, 2(2), 89-102.

Daud, Muhaimin. Andi Artono Dan Eni Prastiti (2018). Pengaruh Kualitas Produk, Citra Merek, Dan Harga Terhadap Minat Beli Produk Sepeda Motor Honda (Studi Pada Mahasiswa Fakultas Ekonomi Manajemen Universitas Kadiri). JIMEK.Volume 1. 70.

Dennisa, Eugenia Andrea dan Suryono Budi Santoso. (2016). Analisis Pengaruh Kualitas Produk, Kualitas Layanan, dan Citra Merek terhadap Loyalitas Pelanggan melalui Kepuasan Pelanggan sebagai Variabel Intervening: Studi pada Klinik Kecantikan Cosmedic Semarang. Journal Of Management. Volume V; 3-3.

Diyagitama, Ahmad Aziz. Hadi Sumarsono dan Naning Kristiyana (2019). Pengaruh Kualitas Produk, Promosi Dan Merek Terhadap Keputusan Pembelian Hp Samsung Di Artomoro Celluler. Jurnal Ekonomi, Manajemen \& Akuntansi Vol. 3 No. 1 April 2019 hal $58-65$

Faisol, Akhmad. 2016. Pengaruh Budaya, Harga dan Lokasi Terhadap Minat Belanja Konsumen di Pasar Soponyono. Jurnal Ilmu dan Riset Manajemen. Vol. 5, No 2.

Fakhru Rizky Nst, Muhammad Dan Hanifa Yasin (2014). Pengaruh Promosi Dan Harga Terhadap Minat Beli Perumahan Obama Pt. Nailah Adi Kurnia Sei Mencirim Medan. Jurnal Manajemen \& Bisnis Vol 14. 137.

Hermanto dan Rendy Saputra (2019). Pengaruh Citra Merek Dan Kualitas Produk Terhadap Minat Beli Konsumen Produk Smartphone Xiaomi (Studi Kasus Di Jakarta Barat). Business Management Journal Vol.15 (No. 1 )

Hidayat, Andrian dan Hartanto, Gustin (2019). Pengaruh Kualitas Produk dan Harga Terhadap Minat Beli Konsumen Smartphone Bergaransi Distributor Pada PT. Tiga Agung. Vol 2. 17. 
Iriyanti, Emik. Nurul Qomariah dan Akhmad Suharto. (2016). Pengaruh Harga, Kualitas Produk Dan Lokasi Terhadap Loyalitas Pelanggan Melalui Kepuasan sebagai Variabel Intervening: pada Depot Mie Pangsit Jember. Jurnal Manajemen Dan Bisnis Indonesia. Volume II; 1-7.

Karundeng, Nikita. Johny A.F. dan Kalangi Olivia Walangitan (2019). Pengaruh Kualitas Produk Terhadap Minat Beli Konsumen Pada Home Industri Pia Deisy Desa Kapitu Kecamatan Amurang Barat. Jurnal Administrasi Bisnis. Vol.8.84.

Latief, Abdul (2018). Analisis Pengaruh Produk, Harga, Lokasi dan Promosi terhadap Minat Beli Konsumen pada Warung Wedang Jahe (Studi Kasus Warung Sido Mampir di Kota Langsa). Jurnal Manajemen Dan Keuangan, Vol.7. 92-95.

Meutia,Rahmi (2017). Analisis Pengaruh Citra Merek, Kualitas Produk dan Harga terhadap Perpindahan Merek (Studi Kasus pada Produk Oriflame di Kota Langsa). Jurnal Manajemen Keuangan. Vol.6.772.

Nurcahyo, Eko. Agus Hermani dan Ngatno. (2017). Pengaruh Harga, Kualitas Produk dan Saluran Distribusi terhadap Loyalitas Pelanggan Surat Kabar Harian Suara Merdeka: Studi Kasus pada Pelanggan di Kecamatan Semarang Selatan. Jurnal Ilmu Administrasi Bisnis.

Pitri Nainggolan, Nora dan Heryenzus (2018). Analisis Faktor-Faktor Yang Mempengaruhi Minat Beli Konsumen Dalam Membeli Rumah Di Kota Batam. Jurnal Ilmiah Manajemen dan Bisnis, Vol 19. 43-54.

Putranto, Arif Dwi. Suprihatmi Sri Wardiningsih dan Suprayitno. (2019). Pengaruh Kualitas Produk, Kualitas Pelayanan dan Promosi terhadap Loyalitas Pelanggan dengan Kepuasan Pelanggan sebagai Variabel Moderasi: Studi pada Pelanggan Brownies Amanda Surakarta Cabang Nusukan. Jurnal Ekonomi dan Kewirausahaan. Volume XVIII; 3-464.

Risnawati (2014). Analisis Pengaruh Kualitas Produk Dan Kualitas Layanan Terhadap Kepuasan Konsumen (Studi Pada Perumahan Komplek Amd Permai Banjarmasin). Jurnal Wawasan Manajemen. Vol. 2. 45.

Rusmawati DJ,Yunni (2018). Pengaruh Kualitas Produk Dan Promosi Terhadap Keputusan Pembelian Produk Smartphone Oppo (Studi Kasus Di Wilayah Kecamatan Karanggeneng Lamongan). Media Mahardhika. Vol. 17 Vol. 17.464.

Septiani, Fauziah (2017). Pengaruh Harga Terhadap Minat Beli (Studi Kasus Pada Pt Asuransi Jiwa Recapital Di Jakarta). J. Mandiri., Vol. 1.278.

Septiani,Fauziah (2018). Pengaruh Promosi Dan Produk Terhadap Minat Beli (Pada Pt. Asuransi Jiwa Recapital Di Jakarta). J. Madani. Vol. 1.401.

Soedjono, Tegowati, \& Wininatin Khamimah (2019). Pengaruh Desain Produk, Kualitas Produk, Promosi, Dan Layanan Purna-Jual Terhadap Keputusan Pembelian Konsumen. Jurnal Akuntansi \& Manajemen. Vol.3. 25.

Sumarsono, Rizkhi, Achmad Firdiansjah dan Harianto Respati (2017). Pengaruh Kualitas Produk, Harga, Dan Citra Merek Terhadap Keputusan Pembelian Produk Madlyson 
Di Distro Aztekline Tulungagung. Jurnal Penelitian Ilmu Ekonomi, Volume 8 Nomor 1 .

Tjia, Heru Sucianto. Suharno dan M.Amin Kadafi . (2017). Pengaruh Harga Kualitas Produk dan Distribusi terhadap Keputusan Pembelian: pada PT Duta Kreasi Tehnik Samarinda. Kinerja. Volume XIV; 2-94.

Wardoyo, Dwityas Adi Kusumo dan Saryadi. (2016). Pengaruh Kualitas Produk, Harga, dan Saluran Distribusi terhadap Loyalitas Pelanggan Majalah SWA Melalui Variabel Kepuasan Pelanggan: Studi Kasus pada Pelanggan Majalah SWA di DKI Jakarta. Jurnal Administrasi Bisnis.

Yessenia dan Febsri Susanti (2018). Pengaruh Bauran Pemasaran Tehadap Minat Beli Konsumen Di Mulia Elektronik Di Kota Padang. Jurnal Ilmu Ekonomi.

Ghozali, Imam. (2011). “Aplikasi Analisis Multivariate Dengan Program SPSS". Semarang: Badan Penerbit Universitas Diponegoro.

Kotler, Philip dan Gary Armstrong, (2001). Prinsip-prinsip Pemasaran, Jilid 1,Edisi Kedelapan,Jakarta,Erlangga.

Muhtarom, Abid., et. al. 2016. Pengantar Ekonomi. UNISLA Press bekerja sama dengan CV. Pustaka Ilalang, Lamongan.

Sugiyono.2016.Metode Penelitian Kuantitatif, Kualitatif dan R\&D. Bandung: PT ALfabet Sugiyono.2018. Metodologi Penelitian.ALFABETA. cv. Bandung

Alma, B. (2016). Pemasaran Jasa. Cetakan Kedua Belas. Bandung: Alfabeta, 205.

Armstrong, G., Adam, S., Denize, S., \& Kotler, P. (2014). Principles of marketing. Pearson Australia.

Daud, M., Artono, A., \& Prastiti, E. (2018). PENGARUH KUALITAS PRODUK, CITRA MEREK, DAN HARGA TERHADAP MINAT BELI PRODUK SEPEDA MOTOR HONDA (STUDI PADA MAHASISWA FAKULTAS EKONOMI MANAJEMEN UNIVERSITAS KADIRI). JIMEK: Jurnal Ilmiah Mahasiswa Ekonomi, 1(1).

Ernawati, D. (2019). Pengaruh Kualitas Produk, Inovasi Produk Dan Promosi Terhadap Keputusan Pembelian Produk Hi Jack Sandals Bandung. JWM (Jurnal Wawasan Manajemen), 7(1), 17-32.

Fernando, M. F., \& Aksari, N. M. A. (2017). Pengaruh Kualitas Produk, Harga, Promosi, Dan Distribusi Terhadap Keputusan Pembelian Produk Sanitary Ware TOTO Di Kota Denpasar. Udayana University.

Ghozali, I. (2016). Aplikasi Analisis Multivariete IBM SPSS 23. Badan Penerbit Universitas Diponegoro, Semarang.

Kotler, P., \& Keller, K. L. (2012). Global Marketing Management 14 th Edition. In Management Decision (14 th, Vol. 48, Issue 8). Prentice Hall/Financial Times. https://doi.org/10.1108/00251741011076816

Kotler, P., \& Keller, K. L. (2016). Marketing Management 15th Global Edition. In England: Pearson Educationn Limited. https://app.luminpdf.com/viewer/99cAGZGug6i5d4dsL 
Mowen, J. C., \& Minor, M. (2006). Understanding consumer behavior: A framework. Thomson.

Nainggolan, N. P., \& Heryenzus, H. (2018). Analisis Faktor-Faktor Yang Mempengaruhi Minat Beli Konsumen Dalam Membeli Rumah Di Kota Batam. Jurnal Ilmiah Manajemen Dan Bisnis, 19(1), 41-54.

Nasution, M. F. R. (2014). Pengaruh promosi dan harga terhadap minat beli perumahan obama PT. Nailah Adi Kurnia SEI Mencirim Medan. Jurnal Ilmiah Manajemen Dan Bisnis, 14(2).

Pangastuti, J., Sudjiono, S., \& Prastiti, E. (2019). Pengaruh Kualitas Produk Dan Harga Terhadap Keputusan Pembelian Produk Kosmetik Wardah Pada Counter Wardah Di Borobudur Kediri. JIMEK: Jurnal Ilmiah Mahasiswa Ekonomi, 2(1), 69-84.

Septiani, F. (2018). PENGARUH PROMOSI DAN PRODUK TERHADAP MINAT BELI. Jurnal Madani: Ilmu Pengetahuan, Teknologi, Dan Humaniora, 1(2), 399-415.

Stanton, W. E. M., Etzel Michael, J., \& Walker Bruce, J. (2007). Fundamentos de marketing. Mc Graw Hill, 581.

Sugiyono. (2016). Metode Penelitian dan Pengembangan (Research and Development/R\&D). In Bandung: Alfabeta. https://doi.org/10.1016/j.drudis.2010.11.005

Tegowati, T. (2019). Pengaruh Desain Produk, Kualitas Produk, Promosi dan Layanan Purna Jual Terhadap Keputusan Pembelian Konsumen. Accounting and Management Journal, 3(1), 23-36.

Wibowo, M. K. (2016). edisi ke 3, Jakarta: PT. Raja Grafindo. 